\title{
Study in indifference
}

Is the British public not interested in science books? Or is it being poorly served by the review media? John Manger of Oxford University Press on the transAtlantic contrasts in the reception accorded to a biography of Albert Einstein.

IN 1982 Oxford University Press published 'Subtle is the Lord' ...The Science and the Life of Albert Einstein, by Abraham Pais. It was judged to be, and remains, a superb piece of scholarship, but not without its problems. Why another Einstein book, asked the doubters, and so soon after the centenary celebration in 1979 ? We took the plunge anyway, in the belief that we had a truly original and saleable book on our hands. So it turned out to be. Over the next year or so over 30,000 hardback copies were bought world-wide, and subsequently a comparable number of copies of the paperback. The distribution of sales, and how the book was treated by the respective review media in Britain and the United States is illuminating.

Of the hardbacks, more than 25,000 were sold in the United States, the remainder in the rest of the world, about 2,500 of them in Britain. To put these figures in perspective, an average scholarly physics monograph would be expected to sell $1,000-1,500$ copies in hardback world-wide, and more often than not would not be published in paperback. Most new novels sell far fewer than 30,000 copies in hardback.

On both sides of the Atlantic, science magazines and those publications largely or completely devoted to reviews did well by the book. In the United States it was reviewed by The New York Review of Books, Science, Physics Today, Scientific American and numerous other weeklies and journals; in Britain by The Times Literary Supplement, The Times Higher Educational Supplement, Nature and New Scientist.

In the United States, however, the book also attracted much wider attention from The New York Times, Los Angeles Times and Christian Science Monitor, as well as from some 30 newspapers across the nation, ranging from the Youngstown (Ohio) Vindicator to the Phoenix (Arizona) Republic. The review in The New York Times was the lead, with picture, in the Sunday books section, perhaps the prime review position in the world. Booksellers, too, were enthusiastic in setting up window displays, while a science book club initially took several thousand copies and then came back for more.

None of the above publicity was particularly exceptional for an American trade publishing house. What was exceptional was the willingness of review editors in such a wide variety of newspapers and magazines to devote space to such a book. It was, after all, not a simple layperson's guide to Einstein, but a scholarly, yet readable, account of the man and his not very simple science.

The book's reception by the "general" media in Britain was in stark contrast. Our approaches to the national weeklies and dailies for review coverage were, in general, met with bewilderment: "Science? We don't have anyone who can review science books"; or "Our readers aren't interested stein, but he's not really very big over here". Who is big over here? In the week we would have expected reviews of 'Subtle is the Lord' the dailies and weeklies were obsessed (in terms of review space) by a volume of the diaries of Beatrice Webb. Many column inches, plus suitable period photographs, were devoted to the earnest, but ultimately trivial, meanderings of this fine Fabian. In the great scheme of things, it is difficult to believe that Einstein is not a more important figure to more people, even in Britain, than Beatrice Webb.

The literary editor would doubtless discount this as a somewhat tendentious conclusion, and retort that these kinds of judgements cannot and should not be made when it comes to deciding which books are reviewed in the national press. A literary editor must do what is best for

\section{IMAGE UNAVAILABLE FOR COPYRIGHT REASONS}

Famous physicist and fine Fabian - Einstein (on a visit to the United States) and Beatrice Webb.

in science"; or "We have 20,000 books a year submitted to us for review, we can't cover them all, you know". The only national newspaper review appeared in The Observer, 17 column inches of it. Otherwise, except for $\mathrm{BBC}$ coverage in Kaleidoscope and on the World Service, the book was virtually ignored. There were no book club sales (there is no scientific book club in Britain).

Two questions arise from this experience. Is the British public not interested in science books? Or is it being poorly served by the review media? Bearing on the first of these is the existence in the United States of the well-known and popular "Physics for Poets" course. Students from most disciplines are encouraged to take at least one science option, and physics "without the sums" is widely taught. Stimulating textbooks are produced in large quantities by college publishers and the end result is a sizeable population of students who have a knowledge of space, time, the nature of the Universe, the atom, crystal structure and, yes, even relativity. More importantly, individuals are not encouraged to think it is somehow smart to be scientifically illiterate.

They will certainly also have an awareness of the importance of a character such as Einstein. One of the more amusing responses to our attempts to attract attention to Pais's book was "Well you'd expect the Americans to be interested in Ein- circulation - quite right. But is it a valid assumption that 99 per cent of the readers of the daily and weekly papers have no interest in science for 99 per cent of the time? Because that is the legitimate conclusion to be drawn from the amount of review space given to science books. It should not be forgotten that not only have the social implications of science never been greater, but that there are hundreds of thousands of practising scientists in Britain some of whom can even read newspapers.

Per head of population, the biography of Einstein sold twice as well in the United States as it did in Britain. But it is nonetheless almost certainly true that there is a greater interest in science in Britain than the media lead themselves to believe. The worrying corollary of their indifference (or plain ignorance) is that publishers will tend to take fewer risks, look for fewer new authors and develop fewer new talents if they feel that science books will be "published without trace". The example of Pais's book demonstrates that science books do not have to be trivial to be saleable in global terms. The pity of it is that the review media in Britain remain stubbornly resistant to educating themselves or their readers.

John Manger is Editorial Director responsible for science and medicine at Clarendon Press, an imprint of Oxford University Press, Walton Street, Oxford $O X 26 D P, U K$. 